\title{
Swedish Jowat Subsidiary with New Managing Director
}

Sintions ince February 2013, Christer Ekstrand has been Managing Director of Jowat Scandinavia AB, the Swedish subsidiary of Jowat AG with headquarters in Malmö. Ekstrand had previously held the position of Director Sales \& Marketing at Lahega Kemi AB, where he was responsible for international customer management.

Supported by his team, the 49-yearold will implement the Jowat strategy of industrial divisions for the Swedish market. The focus will be on establishing the three Management Divisions of Wood/Construction/Furniture, Paper/ Packaging and Automotive/Textile/Electrical in Sweden. "We aim at proving our adhesive competence in all fields of in- dustry, allowing us to act as a partner for our customers," Ekstrand said.

"We are pursuing the strategy of establishing our main industrial divisions also in Scandinavia. In Christer Ekstrand, we now have a competent partner for our customers, who will successfully establish the wide cross-industry adhesive know-how of Jowat AG in Scandinavia”, said Klaus Kullmann, Managing Director on the Board of Jowat AG for Marketing and Sales.

Ekstrand is supported by Per-Anders Lindgren, who has been employed by Jowat Scandinavia AB since 2010 and who will be responsible for the Industrial Division Wood/ Construction/ Furniture.

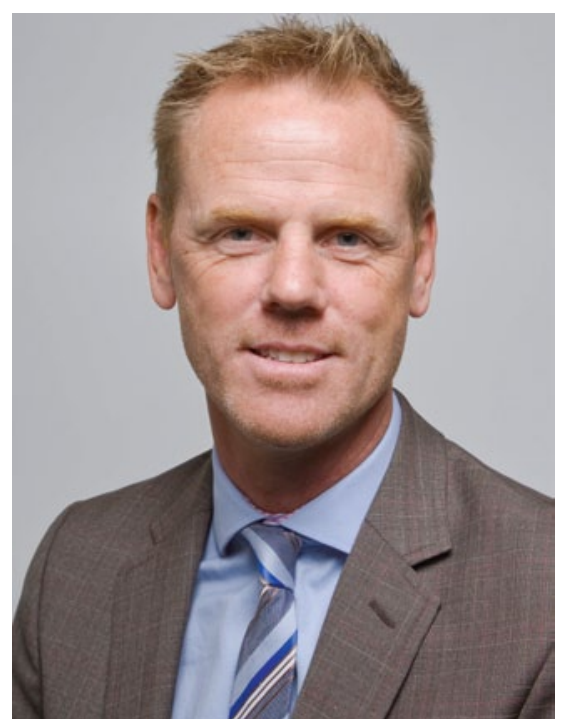

Christer Ekstrand, new Managing Director of Jowat Scandinavia AB

\section{SCA Schucker Aims for Two-Digit Annual Growth}

SCA Schucker, based in Bretten in Germany, achieved a turnover of 110 million euros in 2012 and has set itself the goal of two-digit annual growth. Berthold Peters, the managing director of SCA Schucker, sees the company's best prospects not only in the automotive industry, but also in other high-tech areas.

C CA Schucker, which was established $\checkmark$ in 1986 and taken over by the Atlas Copco Group in 2011, develops systems and machines which enable adhesives

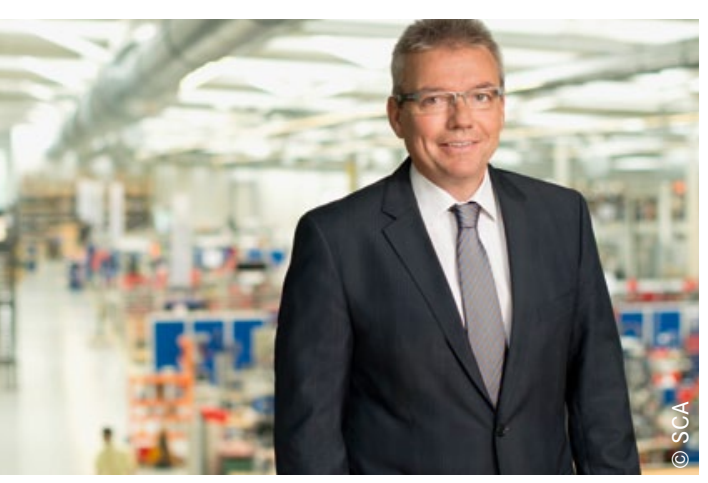

Berthold Peters, managing director of SCA Schucker GmbH \& Co. KG: "Our solutions enable industrial companies to bond materials reliably, flexibly, precisely and quickly, to monitor the quality of their bonded joints more effectively and to increase their productivity." and sealants to be applied manually or automatically. The company currently employs around 400 people worldwide. Around 60 of its employees work in the product development department at its headquarters in Baden-Württemberg, which covers all the necessary technical disciplines. In addition to developing products for specific customers, an area where the company's seven worldwide innovation centres play an important role, the focus in future will also be on strategic product development. The objective of this structured approach is to ensure that the systems and machines are very easy to use and produce reliable results, while keeping life cycle costs low. Dr. Nils Kohlhase, head of research and development at SCA Schucker explains: "In the past, SCA concentrated mainly on customer-specific product development. In future, this will be complemented by a greater emphasis on strategic development."

\section{Global key account management}

In order to provide comprehensive support as a system supplier for its customers in the automotive industry throughout the world, SCA Schucker is also planning to introduce a global key account management function. According to Olaf Leonhardt, head of the automotive industry business unit, this is the only way to achieve long-term success. He believes that global vehicle production will increase from more than 70 million cars annually to more than 90 million. This growth will primarily be generated in Asia. Nevertheless, there remains a significant demand for European brands and technologies. In the automotive industry, for example, SCA dosing systems are used to apply supporting and structur- 